\title{
Epidemiology of Blastocystis sp. infection in China: a systematic review
}

\author{
Lei Deng ${ }^{1, a}$, Yijun Chai ${ }^{1, a}$, Ziyao Zhou ${ }^{1, a}$, Haifeng Liu ${ }^{1}$, Zhijun Zhong ${ }^{1}$, Yanchun Hu ${ }^{1}$, Hualin Fu ${ }^{1}$, \\ Chanjuan $\mathrm{Yue}^{2}$, and Guangneng Peng ${ }^{1, *}$ \\ 1 The Key Laboratory of Animal Disease and Human Health of Sichuan Province, College of Veterinary Medicine, Sichuan Agricultural \\ University, Chengdu, Sichuan 611130, PR China \\ ${ }^{2}$ Sichuan Key Laboratory of Conservation Biology for Endangered Wildlife, Chengdu, Sichuan Province 611130, PR China
}

Received 19 March 2019, Accepted 24 June 2019, Published online 16 July 2019

\begin{abstract}
Blastocystis sp., a unicellular intestinal parasite in humans and animals worldwide, is frequently found in immunocompromized patients and people in close contact with animals. Here, we reviewed recent studies on the prevalence, subtypes, and distribution of Blastocystis infection in humans and animals in China. To date, more than 12 provinces have reported Blastocystis infection in humans, with identification of six different subtypes (ST1, ST2, ST3, ST4, ST5, and ST6). The overall infection rate reported was 3.37\% (3625/107,695), with the lowest prevalence $(0.80 \%)$ in Fujian province and the highest prevalence (100\%) in Guangdong province. ST3 (62\%, 186/300) was the most dominant subtype, identified in all tested provinces in China. A total of eight provinces have reported Blastocystis infection in various animals, with the overall prevalence being $24.66 \%$ (1202/4874). Molecular analysis revealed 14 subtypes that infected animals, including 10 known (ST1, ST2, ST3, ST4, ST5, ST6, ST7, ST10, ST13, ST14), and 4 novel (Novel1, Novel2, Novel3, Novel4) subtypes. ST5 was the dominant subtype infecting artiodactyls $(44.1 \%, 460 / 1044)$, while ST1 commonly infected carnivores $(45.5 \%, 5 / 11)$. These findings provide insights into the epidemiological behavior of Blastocystis sp. in China, and could help in developing effective control strategies against the parasite.
\end{abstract}

Key words: Blastocystis, Molecular epidemiology, China, Zoonosis.

Résumé - Épidémiologie de l'infestation à Blastocystis en Chine : revue systématique. Blastocystis sp., un parasite intestinal unicellulaire de l'homme et des animaux dans le monde entier, est fréquemment détecté chez les patients immunodéprimés et les personnes en contact étroit avec les animaux. Ici, nous avons passé en revue des études récentes sur la prévalence, les sous-types et la distribution de l'infection à Blastocystis chez l'homme et l'animal en Chine. À ce jour, plus de 12 provinces ont signalé une infection à Blastocystis chez l'homme, avec l'identification de 6 sous-types différents (ST1, ST2, ST3, ST4, ST5 et ST6). Le taux d'infection global signalé était de $3,37 \%(3625 / 107695)$, la prévalence la plus faible $(0,80 \%)$ étant dans la province du Fujian et la prévalence la plus élevée (100\%) dans la province du Guangdong. ST3 (62\%, 186/300) était le sous-type le plus dominant, identifié dans toutes les provinces testées en Chine. Au total, 8 provinces ont signalé une infection à Blastocystis chez divers animaux, avec une prévalence globale de 24,66 \% (1202/4874). L'analyse moléculaire a révélé 14 sous-types infectant des animaux, dont 10 sous-types connus (ST1, ST2, ST3, ST4, ST5, ST6, ST7, ST10, ST13, ST14) et 4 nouveaux (Novel1, Novel2, Novel3, Novel4). ST5 était le sous-type dominant infectant les artiodactyles $(44,1 \%, 460 / 1044)$, tandis que ST1 infectait couramment les carnivores $(45,5 \%, 5 / 11)$. Ces résultats fournissent des informations sur le comportement épidémiologique de Blastocystis sp. en Chine et pourrait aider à élaborer des stratégies de contrôle efficaces contre le parasite.

\section{Introduction}

Blastocystis sp. is an anaerobic intestinal parasite infecting humans and several animals [51, 52]. Blastocystis sp. was

\footnotetext{
${ }^{a}$ These authors contributed equally to this work.

*Corresponding author: pgn. sicau@163. com
}

previously thought to be a fungus (non-pathogenic yeast), but was later identified as belonging to the Stramenopiles, a complex and heterogeneous evolutionary assemblage of heterotrophic and photosynthetic protozoa $[38,43]$. The transmission of Blastocystis sp. can be direct or indirect between individuals via the fecal-oral route, which is similar to that observed with some intestinal protozoans, including Cryptosporidium spp., 


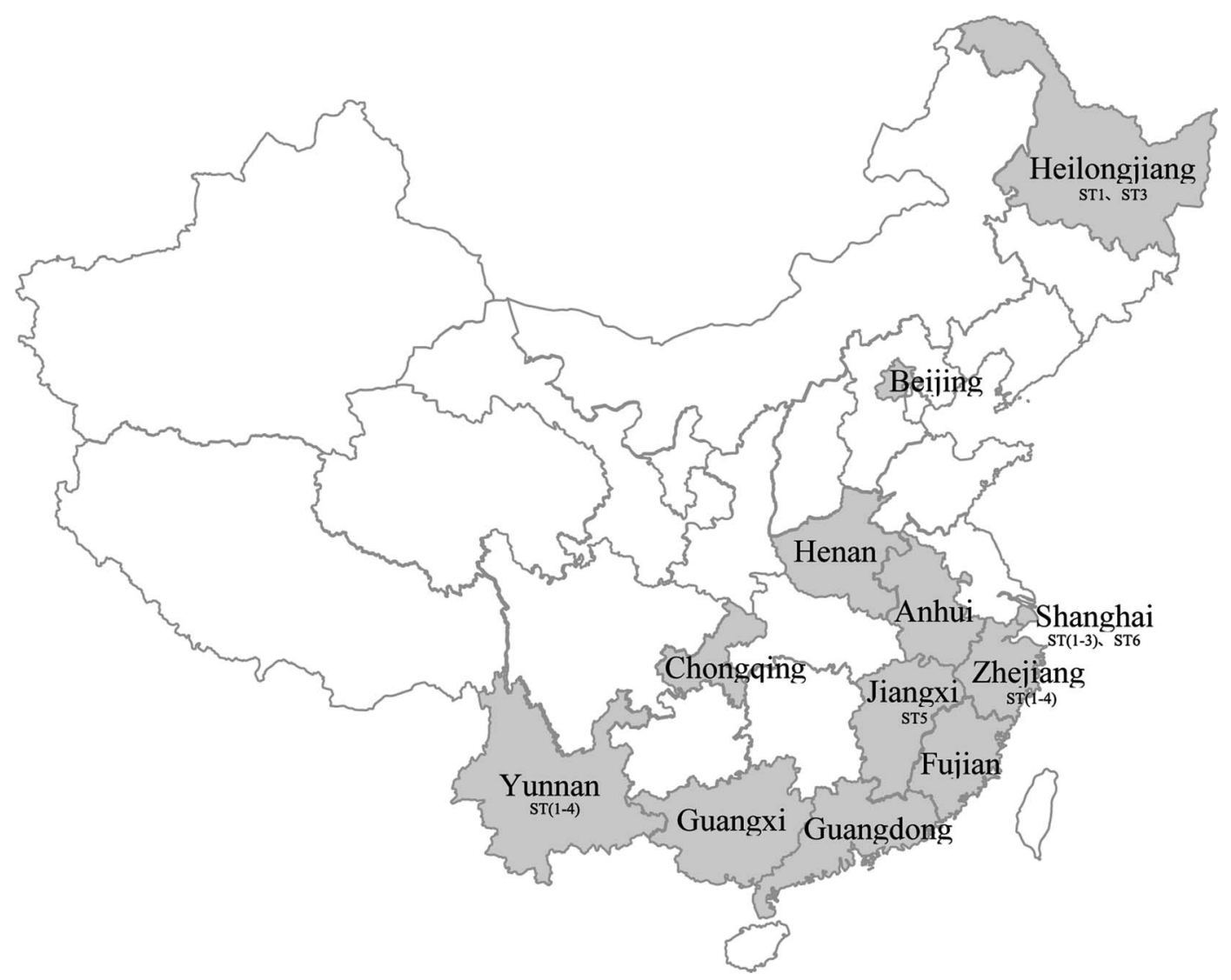

Figure 1. Prevalence of human Blastocystis in different provinces/municipalities in China.

Entamoeba spp., Giardia intestinalis, and Dientamoeba fragilis [49, 63]. Several studies have shown that contaminated water and food with a few number of Blastocystis cysts can establish an infection [17, 62]. Clinical presentations caused by this parasite are very diverse, ranging from self-limiting abdominal discomfort to chronic persistent diarrhea [33]. Frequently, these parasitic infections also present with dermatological symptoms, depending on the different Blastocystis subtypes [14]. Compared to healthy individuals, a higher incidence of Blastocystis has been observed in patients with diarrhea or other gastrointestinal symptoms, especially in patients with irritable bowel syndrome (IBS) symptoms [5, 18]. Since its first descriptions by Alexeieff and Brumpt [12], Blastocystis sp. has been found in a wide host range of animal hosts, including artiodactyls, perissodactyls, proboscideans, rodents and marsupials as well as birds, reptiles, amphibians, fish, annelids, and insects $[31,48]$. Blastocystis sp. is included in the Water, Sanitation, and Health programs of the World Health Organization [58].

Polymerase chain reaction (PCR)-based approaches using feces directly or after culture of fecal specimens have been developed for the diagnosis of Blastocystis infection [27, 39]. More recently, Poirier et al. reported a highly sensitive real-time quantitative PCR (qPCR) assay that targeted a region of the small subunit rRNA gene (SSU-rDNA) and allowed subtyping of isolates in stool samples by direct sequencing of the qPCR products [36]. Moreover, a qPCR assay using the SSU-rDNA marker was also developed, including an internal process control enabling the evaluation of potential PCR inhibitors [8]. Therefore, SSU-rDNA genotyping is the method of choice for diagnosis [8]. Based on SSU-rDNA genotyping, high genetic variability was observed for Blastocystis sp., and 17 known subtypes (ST1-ST17) have been reported [2, 29, $40,41]$. Of these, subtypes 1-9 have been found in humans, with ST1-ST4 as the prevalent subtypes in humans that were identified in $>90 \%$ of investigations [21]. Some human subtypes were also observed in animals, e.g., ST3 in non-human primates, ST5 in cattle and pigs, and ST7 in birds [32]. Additionally, ST5 was commonly detected in pigs and their in-contact handlers (piggery staff) in Australia, indicating the zoonotic potential of this subtype [61].

Owing to its important role in clinical and public health, Blastocystis has attracted the attention of many Chinese scientists, who have made significant contributions to the characterization of Blastocystis sp. and understanding of their biology and transmission. Since the first report of Blastocystis sp. in humans in China in 1996 [24], high prevalence and abundant genetic diversity of Blastocystis sp. have been observed in humans, non-human primates (NHPs), domestic animals (e.g., cattle, sheep, goats, and pigs), and wild animals from many provinces of China. Herein, we review the current knowledge on the epidemiology and subtyping of Blastocystis sp. in humans and animals in China. 
Table 1. Prevalence of Blastocystis sp. in humans in China.

\begin{tabular}{|c|c|c|c|c|c|c|c|}
\hline Location & Method of diagnosis & $\begin{array}{c}\text { No. } \\
\text { examined }\end{array}$ & $\begin{array}{c}\text { No. } \\
\text { positive }\end{array}$ & $\begin{array}{c}\text { Prevalence } \\
(\%)\end{array}$ & Diarrhea & Subtypes $(n)$ & References \\
\hline Guangdong & In vitro culture & 2 & 2 & $100 \%$ & Yes & & [24] \\
\hline \multirow[t]{2}{*}{ Jiangxi } & In vitro culture & 46,900 & 1122 & $2.39 \%$ & Yes & & [59] \\
\hline & PCR & 3 & 3 & $100 \%$ & NG & ST5 (2), ST3 + ST5 (1) & [61] \\
\hline Subtotal & & 469,903 & 1125 & $2.40 \%$ & & ST5 (2), ST3 + ST5 (1) & \\
\hline Anhui & Smear/Iodine/Hematoxylin & 703 & 26 & $3.70 \%$ & Yes & & [57] \\
\hline Chongqing & Smear & 2558 & 35 & $1.37 \%$ & NG & & [54] \\
\hline \multirow[t]{3}{*}{ Guangxi } & Smear/Trichrome & 1354 & 251 & $18.54 \%$ & Yes & & [19] \\
\hline & Smear & 39,671 & 1551 & $3.91 \%$ & Yes & & {$[15]$} \\
\hline & Smear/Iodine & 1185 & 145 & $12.24 \%$ & Yes & & [16] \\
\hline Subtotal & & 42,210 & 1947 & $4.61 \%$ & & & \\
\hline Yunnan & PCR & 239 & 78 & $32.64 \%$ & NG & $\begin{array}{l}\text { ST3 (56), ST1 (16), ST2 (1), } \\
\text { ST4 (1), ST1 and } 2 \text { (1), ST1 } \\
\text { and } 3 \text { (1), Unknown (3) }\end{array}$ & [21] \\
\hline & PCR & 170 & 10 & $5.88 \%$ & NG & ST3 (6), ST1 (3), ST2 (1) & [22] \\
\hline & PCR & 1020 & 37 & $3.63 \%$ & Yes & & [47] \\
\hline & Smear & 215 & 43 & $20.0 \%$ & Yes & & {$[65]$} \\
\hline Subtotal & & 1644 & 168 & $10.22 \%$ & & $\begin{array}{l}\text { ST3 (62), ST1 (19), ST2 (2), } \\
\text { ST4 (1), ST1 and } 2 \text { (1), ST1 } \\
\text { and } 3 \text { (1), Unknown (3) }\end{array}$ & \\
\hline Shanghai & PCR & 1505 & 29 & $1.90 \%$ & NG & $\begin{array}{l}\text { ST3 (17), ST1 (6), ST2 (1), ST6 (1), } \\
\text { ST1 and } 3(2), \\
\text { Unknown (2) }\end{array}$ & [21] \\
\hline Zhejiang & PCR & 646 & 153 & $23.68 \%$ & NG & $\begin{array}{l}\text { ST3 (93), ST1 (38), ST2 (7), } \\
\text { ST4 (1), ST1 and } 3(6), \text { ST1 and } \\
2(1), \text { ST2 and } 3(1), \text { Unknown }(6)\end{array}$ & [21] \\
\hline Beijing & Smear/Trichrome & 122 & 6 & $4.92 \%$ & Yes & & {$[50]$} \\
\hline Henan & $\begin{array}{l}\text { Smear/Iodine/In vitro } \\
\text { culture }\end{array}$ & 369 & 22 & $5.96 \%$ & Yes & & [25] \\
\hline Fujian & Smear/Iodine & 10,652 & 85 & $0.80 \%$ & NG & & [7] \\
\hline Heilongjiang & PCR & 381 & 27 & $7.10 \%$ & Yes & ST1 (12), ST3 (15) & [55] \\
\hline Total & & 107,695 & 3625 & $3.37 \%$ & & $\begin{array}{l}\text { ST3 (186), ST1 (75), ST2 (10), } \\
\text { ST4 (2), ST5 (2), ST6 (1), ST1 and } \\
3(9), \text { ST1 and } 2 \text { (2), ST2 and } 3(1), \\
\text { ST3 + ST5 (1), Unknown (11) }\end{array}$ & \\
\hline
\end{tabular}

NG: Not given.

\section{Characteristics and distribution of Blastocystis sp. in humans}

Human Blastocystis sp. infection has been widely reported in the world, in developing countries (Iran, Jordan, Argentina, Egypt, Thailand, Philippines, Malaysia, Zambia, Indonesia, Chile, and China) as well as developed countries (Japan, Singapore, England, Spain, Italy, Germany, United States, and Turkey) [30, 42, 46]. The first description of Blastocystis sp. infection in China was reported in two children with chronic diarrhea from Guangdong province [24]. Subsequently, more than 12 provinces/municipalities have reported Blastocystis sp. infection in China (Fig 1). Most of these reports investigated Blastocystis sp. infection in patients with diarrhea [19, 50], and the prevalence ranged from $0.80 \%$ to $100 \%$ (Table 1 ). The average prevalence was $3.37 \%(3625 / 107,695)$, with the highest infection rate being $32.6 \%$, (78/239) reported using PCR amplification of the SSU-rDNA gene of Blastocystis sp. in Yunnan province [22], and the lowest rate being $0.80 \%$, (85/ 10,652) determined by a method using direct saline smear and iodine staining in Fujian province [7].
The prevalence of Blastocystis sp. infection may be affected by many factors, such as the immune status of hosts, different geographic locations, age of hosts, and eating habits. For example, the prevalence was higher in patients with different degrees of diarrhea than in those without gastrointestinal illnesses [57, 65]. The prevalence was also higher in rural communities than in urban residents $[7,54]$, and higher prevalence was observed in the southern regions with less developed inland areas compared with that in the northern coastal provinces [21, 47]. Further, the infection rate was higher in people aged from 18 to 39 years than in children $<5$ years of age in Yunnan province [22], which was consistent with the observations in Guangxi [15] and Heilongjiang provinces [66]. In addition, infection with Blastocystis sp. was associated with drinking un-boiled water in a hilly village in the Yunnan province of southern China [22]. In 2000, there was an outbreak of Blastocystis sp. infection, in which humans were infected through ingestion of contaminated running water, and more than 1122 patients with diarrhea were identified [59]. These results suggest that Blastocystis sp. might be transmitted by contaminated water to humans in China. 


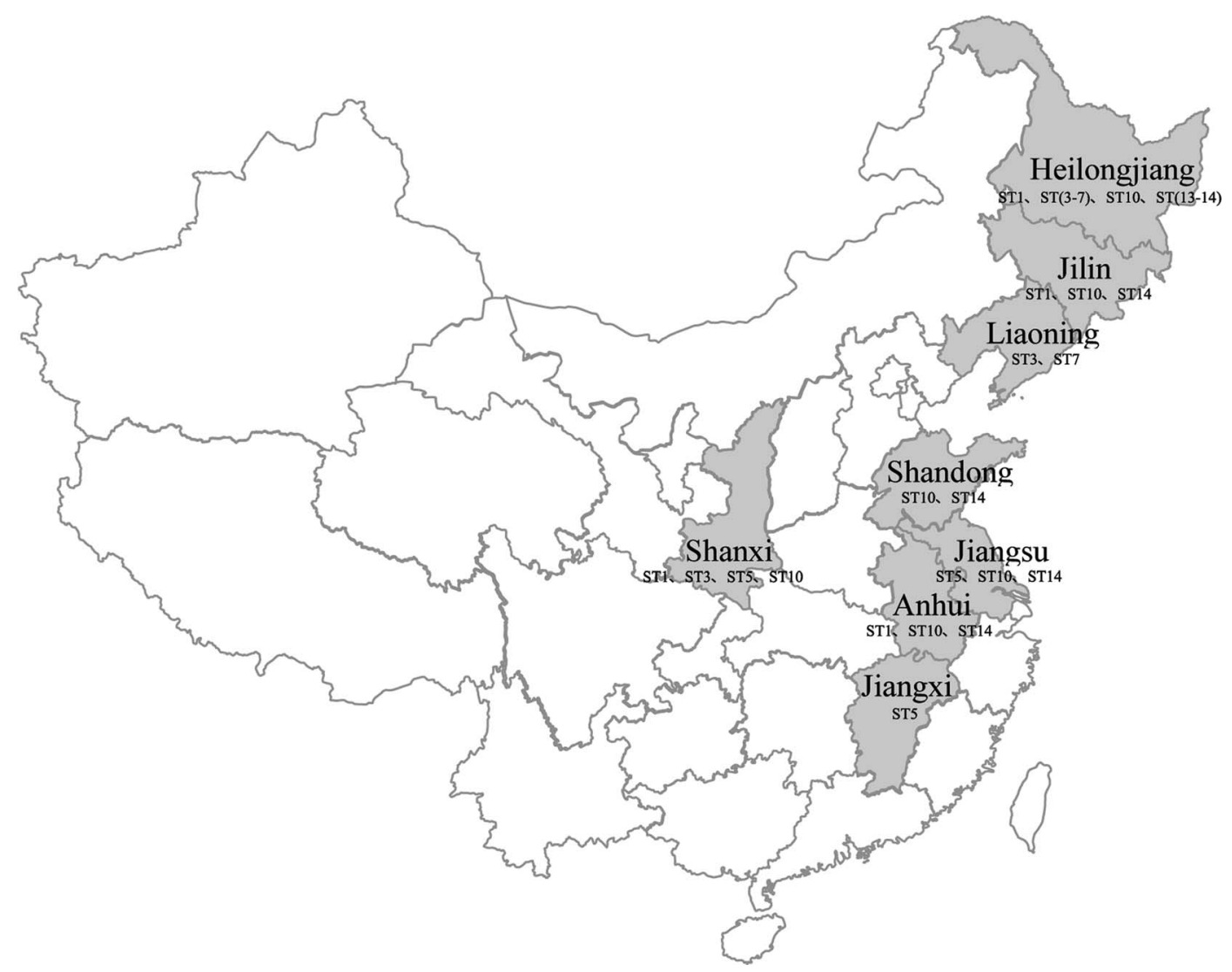

Figure 2. Prevalence of animal Blastocystis in different provinces/municipalities in China.

Sequence analysis of the barcode region of the SSU rRNA gene in isolates identified a total of six different Blastocystis sp. subtypes in China (Table 1). Most of the samples represented single-subtype infections (ST1, ST2, ST3, ST4, ST5, and ST6), while mixed infections were also observed $(\mathrm{ST} 1+2$, $\mathrm{ST} 1+3, \mathrm{ST} 2+3, \mathrm{ST} 3+5)$, and some subtypes were novel (unknown). Among them, ST3 (62\%, 186/300) was the most dominant subtype of Blastocystis sp., and was identified in almost all studies reported in China based on PCR analysis. A large majority of human infections were also attributable to the ST3 isolates reported in Europe, Africa, Oceania, and the Middle East [13, 32, 43, 48].

\section{Characteristics and distribution of Blastocystis sp. in animals}

Blastocystis sp. has been isolated from a variety of animals worldwide, including in Spain, the UK, Czechoslovakia, Japan, Thailand, Malaysia, Ethiopia, Indonesia, Chile, Australia, Singapore, and China [30]. The prevalence varies from $1.8 \%$ identified in cattle in Spain to $100 \%$ identified in chickens in Japan [28, 37]. In China, Blastocystis infection has been reported in 25 different species among the orders Artiodactyla, Carnivora, Galliformes, Primates, Columbiformes, Anseriformes, Gruiformes, Rodentia, and Lagomorpha from eight different provinces (Fig. 2). The average infection rate was $24.66 \%$ (1202/4874), with the prevalence of infection varying markedly among different orders and different geographical areas in China (Table 2).

In Artiodactyla, pigs, cattle, sheep, goats, and deer are the commonly infected animals, with the prevalence ranging from $0.35 \%$ to $100 \%$. Infection in pigs and cattle is also the most common in other countries, such as in Japan [1] (70.9\% in cattle and $95.1 \%$ in pigs), and Spain (1.8\% in cattle and $46.8 \%$ in pigs) [34]. The first report of Blastocystis sp. infection in sheep was from Heilongjiang province in 2018 [55]. Li et al. found that the highest infection rate of Blastocystis sp. in sheep was $16.67 \%$ [23], which was lower than that in sheep in the UK (23.5\%) [2, 3] and Malaysia (30.9\%) [53]. Variable prevalence was observed in different species of deer, ranging from $6.73 \%$ to $100 \%$ (Table 2). Molecular characterization of these Blastocystis sp. isolates from Artiodactyla indicated 11 subtypes, including 7 known subtypes (ST1, ST3, ST4, ST5, ST10, ST13, ST14) and 4 novel subtypes (Novel1, Novel2, Novel3, Novel4). Among these subtypes, ST5 was the most prevalent, accounting for $44.1 \%$ (460/1044). Interestingly, ST5 has been identified in humans and pigs in the rural areas of Jiangxi province, where many households keep small pigs, with pigs and children sometimes sharing common outdoor areas [61]. These reports suggest that ST5 shows zoonotic potential and pigs may be a potential source of infection in these rural areas.

In Carnivora, Blastocystis sp. infection has been commonly found in raccoon dogs $(6.25-8.33 \%)$, domestic dogs (1.61$16.7 \%)$, and arctic foxes (1.73-2.5\%). A total of four subtypes 
Table 2. Prevalence of Blastocystis sp. in animals in China.

\begin{tabular}{|c|c|c|c|c|c|c|c|c|}
\hline Order & Location & $\begin{array}{l}\text { Method of } \\
\text { diagnosis }\end{array}$ & $\begin{array}{l}\text { Hosts } \\
\text { (Scientific name) }\end{array}$ & $\begin{array}{c}\text { No. } \\
\text { examined }\end{array}$ & $\begin{array}{c}\text { No. } \\
\text { positive }\end{array}$ & $\begin{array}{c}\text { Prevalence } \\
(\%)\end{array}$ & Subtypes $(n)$ & References \\
\hline \multirow[t]{18}{*}{ Artiodactyla } & Shanxi & Smear/Iodine & Wild boars (Sus scrofa) & 5 & 1 & $20.0 \%$ & & [6] \\
\hline & Shanxi & Smear/Iodine & $\begin{array}{l}\text { Himalayan Goral } \\
\text { (Naemorhedus goral) }\end{array}$ & 11 & 2 & $18.20 \%$ & & [6] \\
\hline & Shanxi & PCR & Pig & 560 & 419 & $74.82 \%$ & $\begin{array}{l}\text { ST5 (397), ST1 (15), } \\
\text { ST3 (6), ST10 (1) }\end{array}$ & [44] \\
\hline & Jiangxi & PCR & Pig & 16 & 16 & $100 \%$ & ST5 (16) & {$[61]$} \\
\hline & Heilongjiang & PCR & Pig & 68 & 6 & $8.82 \%$ & ST5 (6) & [55] \\
\hline & Heilongjiang & PCR & Cattle & 147 & 14 & $9.52 \%$ & $\begin{array}{l}\text { ST10 (10), ST3 (2), } \\
\text { ST14 (2) }\end{array}$ & {$[55]$} \\
\hline & Heilongjiang & PCR & Dairy cattle & 526 & 54 & $10.27 \%$ & $\begin{array}{l}\text { ST10 (41), ST14 (10), } \\
\text { ST4 (2), ST5 (1) }\end{array}$ & {$[45]$} \\
\hline & Heilongjiang & PCR & Sheep & 109 & 6 & $5.50 \%$ & $\begin{array}{l}\text { ST10 (3), ST1 (1), } \\
\text { ST5 (1), ST14 (1) }\end{array}$ & {$[55]$} \\
\hline & Anhui & PCR & Sheep & 697 & 22 & $3.16 \%$ & $\begin{array}{l}\text { ST10 (14), ST14 (3), } \\
\text { Novel } 1 \text { (3), Novel } 2 \text { (1), } \\
\text { Novel } 3 \text { (1) }\end{array}$ & [23] \\
\hline & Jiangsu & PCR & Sheep & 75 & 18 & $24.0 \%$ & $\begin{array}{l}\text { ST5 (8), ST10 (5), } \\
\text { ST14 (5) }\end{array}$ & {$[23]$} \\
\hline & Shandong & PCR & Sheep & 60 & 10 & $16.67 \%$ & $\begin{array}{l}\text { ST10 (6), ST14 (2), } \\
\text { Novel } 4 \text { (2) }\end{array}$ & [23] \\
\hline & Shanxi & PCR & Goat & 789 & 458 & $58.05 \%$ & $\begin{array}{l}\text { ST10 (292), ST14 (123), } \\
\text { ST5 (31), ST4 (9), } \\
\text { ST1 (1), ST3 (1), } \\
\text { Novel (1) }\end{array}$ & [43] \\
\hline & Anhui & PCR & Goat & 574 & 2 & $0.35 \%$ & ST1 (2) & [43] \\
\hline & Heilongjiang & PCR & $\begin{array}{l}\text { Reindeer } \\
\quad \text { (Rangifer tarandus) }\end{array}$ & 104 & 7 & $6.73 \%$ & ST13 (4), ST10 (3) & {$[56]$} \\
\hline & Heilongjiang & PCR & $\begin{array}{l}\text { Sika deer } \\
\quad \text { (Cervus nippon })\end{array}$ & 52 & 6 & $11.54 \%$ & ST10 (6) & {$[56]$} \\
\hline & Jilin & PCR & $\begin{array}{l}\text { Sika deer (Cervus } \\
\text { nippon) }\end{array}$ & 30 & 6 & $20 \%$ & ST10 (4), ST14 (2) & {$[56]$} \\
\hline & Shanxi & Smear/Iodine & $\begin{array}{l}\text { Barking Deer } \\
\quad(\text { Muntiacus muntjak) }\end{array}$ & 2 & 2 & $100 \%$ & & {$[6]$} \\
\hline & Shanxi & Smear/Iodine & $\begin{array}{l}\text { Sika deer (Cervus } \\
\text { nippon) }\end{array}$ & 3 & 1 & $33.33 \%$ & & [6] \\
\hline Subtotal & & & & 3828 & 1050 & $27.43 \%$ & $\begin{array}{l}\text { ST5 (460), ST10 (385), } \\
\text { ST14 (148), ST1 (19), } \\
\text { ST4 (11), ST3 (9), } \\
\text { ST13 (4), Novel1 (4), } \\
\text { Novel2 (1), Novel3 (1), } \\
\text { Novel4 (2) }\end{array}$ & \\
\hline \multirow[t]{6}{*}{ Carnivora } & Heilongjiang & PCR & $\begin{array}{l}\text { Racoon dog (Nyctereutes } \\
\text { procyonoides) }\end{array}$ & 16 & 1 & $6.25 \%$ & ST3 (1) & [56] \\
\hline & Liaoning & PCR & $\begin{array}{l}\text { Racoon dog (Nyctereutes } \\
\text { procyonoides) }\end{array}$ & 24 & 2 & $8.33 \%$ & ST3 (2) & {$[56]$} \\
\hline & Heilongjiang & PCR & Domestic dog & 124 & 2 & $1.61 \%$ & ST1 (1), ST4 (1) & {$[56]$} \\
\hline & Jilin & PCR & Domestic dog & 12 & 2 & $16.67 \%$ & ST1 (2) & {$[56]$} \\
\hline & Liaoning & PCR & $\begin{array}{l}\text { Arctic fox (Vulpes } \\
\quad \text { lagopus) }\end{array}$ & 40 & 1 & $2.5 \%$ & ST7 (1) & {$[56]$} \\
\hline & Heilongjiang & PCR & $\begin{array}{l}\text { Arctic fox (Vulpes } \\
\text { lagopus) }\end{array}$ & 173 & 3 & $1.73 \%$ & ST1 (2), ST4 (1) & {$[56]$} \\
\hline Subtotal & & & & 389 & 11 & $2.83 \%$ & $\begin{array}{l}\text { ST1 (5), ST3 (3), } \\
\text { ST4 (2), ST7 (1) }\end{array}$ & \\
\hline \multirow[t]{3}{*}{ Galliformes } & Shanxi & Smear/Iodine & Peafowl (Pavonini) & 9 & 3 & $33.33 \%$ & & [6] \\
\hline & Shanxi & Smear/Iodine & $\begin{array}{l}\text { Brown-eared pheasant } \\
\quad \text { (Crossoptilon } \\
\text { mantchuricum) }\end{array}$ & 2 & 2 & $100 \%$ & & [6] \\
\hline & Shanxi & Smear/Iodine & $\begin{array}{l}\text { Crimson-bellied } \\
\text { tragopan (Tragopan } \\
\text { temminckii) }\end{array}$ & 2 & 1 & $50 \%$ & & {$[6]$} \\
\hline
\end{tabular}


Table 2. (Continued)

\begin{tabular}{|c|c|c|c|c|c|c|c|c|}
\hline Order & Location & $\begin{array}{l}\text { Method of } \\
\text { diagnosis }\end{array}$ & $\begin{array}{l}\text { Hosts } \\
\text { (Scientific name) }\end{array}$ & $\begin{array}{c}\text { No. } \\
\text { examined }\end{array}$ & $\begin{array}{c}\text { No. } \\
\text { positive }\end{array}$ & $\begin{array}{c}\text { Prevalence } \\
(\%)\end{array}$ & Subtypes $(n)$ & References \\
\hline & Shanxi & Smear/Iodine & $\begin{array}{l}\text { Golden pheasant } \\
\quad \text { (Chrysolophus pictus) }\end{array}$ & 11 & 10 & $90.91 \%$ & & [6] \\
\hline & Heilongjiang & PCR & Domestic chicken & 46 & 6 & $13.04 \%$ & ST6 (3), ST7 (3) & [56] \\
\hline Subtotal & & & & 70 & 22 & $31.43 \%$ & ST6 (3), ST7 (3) & \\
\hline \multirow[t]{2}{*}{ Primates } & Shanxi & Smear/Iodine & $\begin{array}{l}\text { Golden monkey } \\
\quad \text { (Rhinopithecus) }\end{array}$ & 12 & 8 & $66.67 \%$ & & [6] \\
\hline & China $^{\mathrm{a}}$ & PCR & $\begin{array}{l}\text { Cynomolgus macaques } \\
\text { (Macaca fascicularis) }\end{array}$ & 97 & 85 & $87.63 \%$ & $\begin{array}{l}\text { ST1 (4), ST2 (14), ST7 } \\
\text { (2), ST2 + ST1 (14), ST2 } \\
+ \text { ST3 (5), ST2 + ST7 (5), } \\
\text { ST3 + ST1 (3), ST5 + ST2 } \\
(1), \text { ST7 + ST1 (7), ST7 + } \\
\text { ST3 (1), ST1 + ST2 + ST3 } \\
(10), \text { ST1 + ST2 + ST7 } \\
\text { (5), ST2 + ST3 + ST7 (3), } \\
\text { ST1 + ST3 + ST7 (1), ST1 } \\
+ \text { ST2 + ST3 + ST7 (10) }\end{array}$ & . \\
\hline Subtotal & & & & 109 & 93 & $85.32 \%$ & $\begin{array}{l}\text { ST1 (4), ST2 (14), ST7 } \\
(2), \text { ST2 + ST1 (14), ST2 } \\
+ \text { ST3 (5), ST2 + ST7 (5), } \\
\text { ST3 + ST1 (3), ST5 + ST2 } \\
(1), \text { ST7 + ST1 (7), ST7 + } \\
\text { ST3 (1), ST1 + ST2 + ST3 } \\
(10), \text { ST1 + ST2 + ST7 } \\
(5), \text { ST2 + ST3 + ST7 (3), } \\
\text { ST1 + ST3 + ST7 (1), ST1 } \\
+ \text { ST2 + ST3 + ST7 (10) }\end{array}$ & \\
\hline \multirow[t]{2}{*}{ Columbiformes } & Heilongjiang & PCR & Pigeon & 47 & 1 & $2.13 \%$ & ST6 (1) & [56] \\
\hline & Shanxi & Smear/Iodine & $\begin{array}{l}\text { Crested ibis } \\
\quad \text { (Nipponia nippon) }\end{array}$ & 63 & 6 & $9.53 \%$ & & \\
\hline Subtotal & & & & 110 & 7 & $6.36 \%$ & ST6 (1) & \\
\hline Anseriformes & Shanxi & Smear/Iodine & $\begin{array}{l}\text { Whooper swan } \\
\text { (Cygnus cygnus) }\end{array}$ & 2 & 2 & $100 \%$ & & [6] \\
\hline Gruiformes & Heilongjiang & PCR & $\begin{array}{l}\text { Red crowned crane } \\
\quad \text { (Grus japonensis) }\end{array}$ & 43 & 6 & $13.95 \%$ & ST6 (4), ST7 (2) & [56] \\
\hline Rodentia & Heilongjiang & PCR & $\begin{array}{l}\text { Brown rat (Rattus } \\
\text { norvegicus) }\end{array}$ & 108 & 4 & $3.70 \%$ & ST4 (4) & [56] \\
\hline Lagomorpha & Heilongjiang & PCR & $\begin{array}{l}\text { New Zealand white } \\
\text { rabbit }\end{array}$ & 215 & 7 & $3.24 \%$ & ST4 (7) & {$[56]$} \\
\hline Total & & & & 4874 & 1202 & $24.66 \%$ & $\begin{array}{l}\text { ST5 (460), ST10 (385), } \\
\text { ST14 (148), ST1 (28), } \\
\text { ST4 (24), ST2 (14), ST3 } \\
\text { (12), ST6 (8), ST7 (8), } \\
\text { ST13 (4), ST2 + ST1 (14), } \\
\text { ST2 + ST3 (5), ST2 + ST7 } \\
\text { (5), ST3 + ST1 (3), ST5 + } \\
\text { ST2 (1), ST7 + ST1 (7), } \\
\text { ST7 + ST3 (1), ST1 + ST2 } \\
\text { + ST3 (10), ST1 + ST2 + } \\
\text { ST7 (5), ST2 + ST3 + ST7 } \\
\text { (3), ST1 + ST3 + ST7 (1), } \\
\text { ST1 + ST2 + ST3 + } \\
\text { ST7 (10), Novel (4), } \\
\text { Novel4 (2), Novel2 (1), } \\
\text { Novel3 (1) }\end{array}$ & \\
\hline
\end{tabular}

\footnotetext{
${ }^{\text {a }}$ fecal samples from registered breeding facilities in China (F2 purpose-bred).
}

of Blastocystis sp. were identified (ST1, ST3, ST4, ST7), with ST1 being the most prevalent subtype (Table 2). Importantly, ST1 has been identified in humans in the same region, indicating that ST1 might have the ability to transmit between humans and dogs [66]. Similarly, ST1 has been identified in dogs and their owners in Australia [33], the Philippines, and 


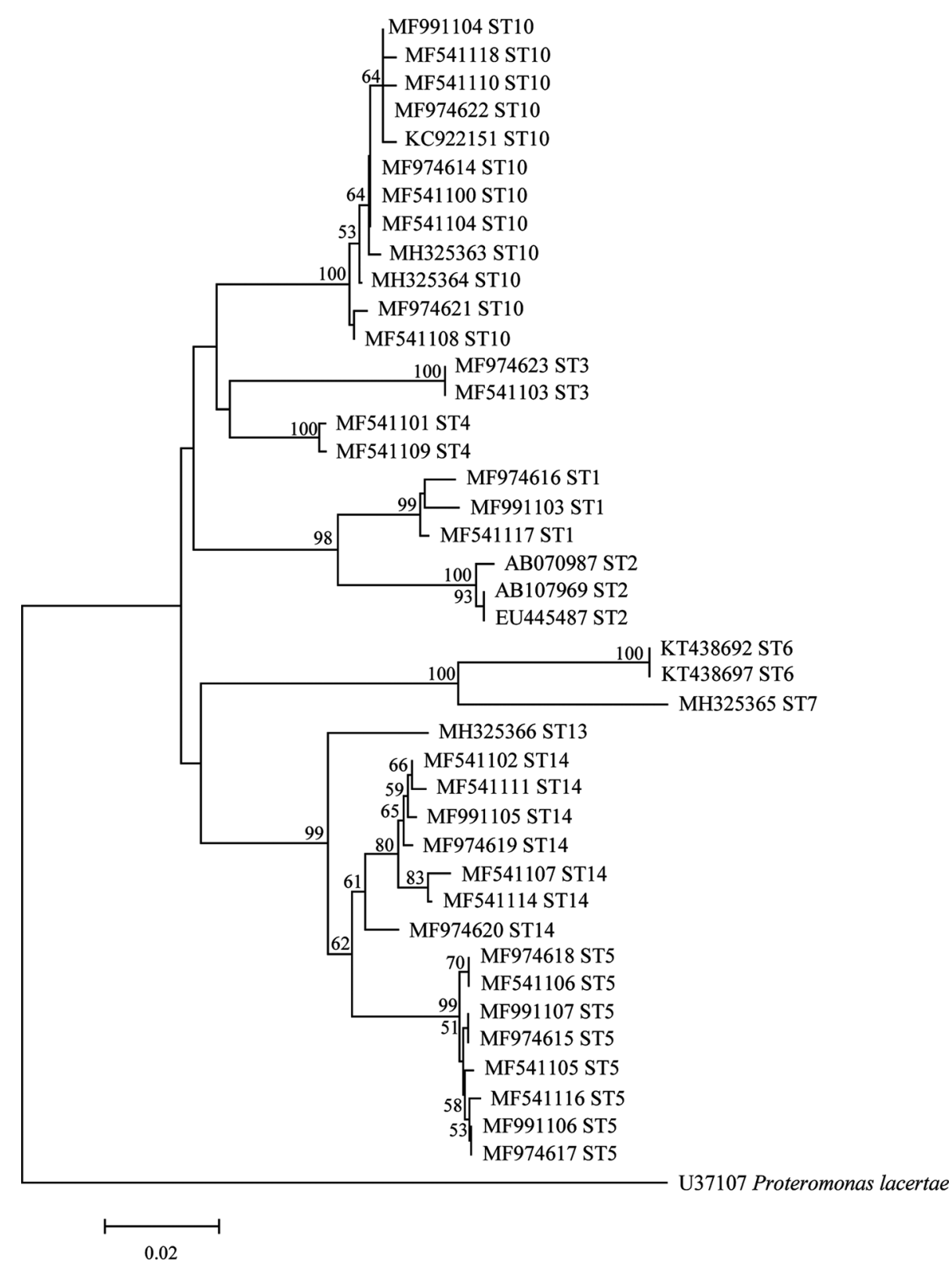

Figure 3. Phylogenetic relationships among the representative sequences of the Blastocystis small subunit ribosomal RNA (SSU rRNA) gene obtained from China, using the neighbor-joining method. The trees were rooted with GenBank sequence U37107. Bootstrap values greater than $50 \%$ from 1000 pseudoreplicates are shown.

Turkey [4], suggesting that dogs could be involved in the transmission of Blastocystis to humans.

In Galliformes, the peafowl (33.3\%), brown-eared pheasant $(100 \%)$, crimson-bellied tragopan $(50 \%)$, golden pheasant (90.9), and domestic chicken (13\%) have presented with Blastocystis infection. Among these, the prevalence of infection among chickens is consistent with that reported in Australia (74.4\%) [20] and Japan (100\%) [60]. Pigeon and crested ibis, belonging to Columbiformes, show prevalence of Blastocystis sp. of $2.13 \%$ and $9.53 \%$, respectively. In both Anseriformes and Gruiformes, only one species has been identified with Blastocystis infection at present, respectively (Table 2). ST6 and ST7, identified in these orders, are the most common subtypes in birds and are generally considered to be avian subtypes [9]. In addition to birds, the two subtypes are occasionally found in some mammals: ST6 in pigs, cattle, goats, and dogs [55, 56]; ST7 in pigs, goats, cynomolgus monkeys, ruffed lemurs, and dogs [64]. In humans, ST6 and ST7 only constitute a small share (approximately 9\%) of cases of blastocystosis $[2,3]$.

In primates, golden monkeys and cynomolgus macaques have been identified with Blastocystis sp. infection, the average prevalence being $85.32 \%$, which was higher than that observed in primates in Australia (2.1\%) [35], Malaysia (53.8\%) [26], and Spain $(66.6 \%)$ [11]. ST2 was the most prevalent subtype, and mixed infection was observed in this order (Table 2). Brown rat and New Zealand white rabbit, belonging to Rodentia and Lagomorpha respectively, show similar prevalences of 
infection $(3.70 \%$ and $3.24 \%$, respectively). ST4 is the most common in rodents and is also one of the four most common subtypes in humans (ST1-ST4) [10].

Phylogenetic relationships were analyzed by the neighborjoining method under the Kimura 2-parameter model using Mega 6 (http://www.megasoftware.net/), and a bootstrap analysis with 1000 replicates was performed to assess the robustness of clusters (Figure 3).

\section{Conclusions and perspectives}

Since its first discovery in China in 1996, knowledge of the epidemiology of Blastocystis sp. has progressed significantly, with more than 12 provinces/municipalities having reported Blastocystis sp. infection in humans, and in over 25 different animal hosts. A total of 6 and 14 different subtypes of Blastocystis sp. have been identified in humans and animals, respectively. The most dominant subtype identified is ST3 in humans and ST5 in animals. Some subtypes (ST1, ST3, and ST5) have been found in humans and animals in the same province, suggesting that these zoonotic subtypes can be transmitted between humans and animals.

Additionally, although there is some evidence of fecal-oral transmission of the cyst form of Blastocystis, the actual mode of transmission among the various hosts and/or transmission between animals and humans has not yet been conclusively demonstrated. There is increasing evidence of the zoonotic potential of this parasite, although correlations between potential zoonotic subtypes and pathogenicity are still under debate. Therefore, more studies should be conducted to evaluate the pathogenicity, route of transmission, and host specificity of different Blastocystis sp. subtypes.

\section{Conflict of interest}

The authors declare that they have no conflict of interest.

Acknowledgements. The study was supported by the Chengdu Giant Panda Breeding Research Foundation (CPF2017-12, CPF2015-09, CPF2015-07).

\section{References}

1. Abe N, Nagoshi M, Takami K, Sawano Y, Yoshikawa H. 2002. A survey of Blastocystis sp. in livestock, pets, and zoo animals in Japan. Veterinary Parasitology, 106, 203-212.

2. Alfellani MA, Stensvold CR, Vidal-Lapiedra A, Onuoha ESU, Fagbenro-Beyioku AF, Clark CG. 2013. Variable geographic distribution of Blastocystis subtypes and its potential implications. Acta Tropica, 126, 11-18.

3. Alfellani MA, Taner-Mulla D, Jacob AS, Imeede CA, Yoshikawa H, Stensvold CR, Clark CG. 2013. Genetic diversity of Blastocystis in livestock and zoo animals. Protist, 164, 497-509.

4. Belleza ML, Reyes JC, Tongol-Rivera PN, Rivera WL. 2016. Subtype analysis of Blastocystis sp. isolates from human and canine hosts in an urban community in the Philippines. Parasitology International, 65, 291-294.
5. Boorom KF, Smith H, Nimri L, Viscogliosi E, Spanakos G, Parkar U, Li LH, Zhou XN, Ok ÜZ, Leelayoova S. 2008. Oh my aching gut: irritable bowel syndrome, Blastocystis, and asymptomatic infection. Parasites \& Vectors, 1, 40-40.

6. Cai J, Qiao JY, Zhang X, Jin XL, Ren JS, Ma QY, Wu XM. 2009. Observation on intestinal parasitic morphology and infection in captive rare wildlife in Shaanxi Province. Chinese Journal of Zoology, 44, 63-69.

7. Chen BJ, Xie HG, Zhan RY, Li YR, Lin CX, Xie XL, Jian DW, Zhang SY. 2018. Human intestinal protozoa diseases in Fujian Province, China. Chinese Journal of Zoonoses, 34, 6.

8. Christen Rune S, Umran Nisar A, Lee O'Brien A, Henrik Vedel N. 2012. Development and evaluation of a genusspecific, probe-based, internal-process-controlled real-time PCR assay for sensitive and specific detection of Blastocystis spp. Journal of Clinical Microbiology, 50, 1847-1851.

9. Cian A, El SD, Osman M, Moriniere R, Gantois N, BenamrouzVanneste S, Delgado-Viscogliosi P, Guyot K, Li LL, Monchy S. 2017. Molecular epidemiology of Blastocystis sp. in various animal groups from two French zoos and evaluation of potential zoonotic risk. PLoS One, 12, e0169659.

10. Clark CG, Van dGM, Alfellani MA, Stensvold CR. 2013. Recent developments in Blastocystis research. Advances in Parasitology, 82, 1-32.

11. Cordón GP, Prados AH, Romero D, Moreno MS, Pontes A, Osuna A, Rosales MJ. 2008. Intestinal parasitism in the animals of the zoological garden "Peña Escrita" (Almuñecar, Spain). Veterinary Parasitology, 156, 302-309.

12. Brumpt E. 1912. Blastocystis hominis $\mathrm{n}$ sp. et formes voisines. Bull Soc Pathol Exot, 5, 725-730.

13. Forsell J, Granlund M, Stensvold CR, Clark CG, Evengård B. 2012. Subtype analysis of Blastocystis isolates in Swedish patients. European Journal of Clinical Microbiology \& Infectious Diseases, 31, 1697.

14. Hameed DMA, Hassanin OM, Nehal Mohamed ZF. 2011. Association of Blastocystis hominis genetic subtypes with urticaria. Parasitology Research, 108, 553-560.

15. Hu Y, Li YW, Lu ZC. 2012. Clinical analysis of Blastocystis hominis infection in 1185 patients with chronic diarrhea in 2011. China Tropical Medicine, 12, 713-718.

16. Hu Y, Lu ZC, Shi HH. 2012. Survey of intestinal parasitic infections in hospitalized patients. China Tropical Medicine, 12, 1382-1395.

17. Ithoi I, Jali A, Mak JW, Yusoff WSW, Mahmud R. 2011. Occurrence of Blastocystis in water of two rivers from recreational areas in Malaysia. Journal of Parasitology Research, 2011, 123916.

18. Jimenez-Gonzalez DE, Martinez-Flores WA, Reyes-Gordillo J, Ramirez-Miranda ME, Arroyo-Escalante S, Romero-Valdovinos M, Stark D, Souza-Saldivar V, Martinez-Hernandez F, Flisser A. 2012. Blastocystis infection is associated with irritable bowel syndrome in a Mexican patient population. Parasitology Research, 110, 1269-1275.

19. Jin QX, Yu KM, Tang LF, Tian CL, Lu ZC. 2005. Investigation of infectious status of Blastocystis hominis in 1354 outpatients. China Tropical Medicine, 5, 1469-1471.

20. Lee MG, Stenzel DJ. 1999. A survey of Blastocystis in domestic chickens. Parasitology Research, 85, 109-117.

21. Li LH, Zhang XP, Lv S, Zhang L, Yoshikawa H, Wu Z, Steinmann P, Utzinger J, Tong XM, Chen SH. 2007. Crosssectional surveys and subtype classification of human Blastocystis isolates from four epidemiological settings in China. Parasitology Research, 102, 83-90.

22. Li LH, Zhou XN, Du ZW, Wang XZ, Wang LB, Jiang JY, Yoshikawa H, Steinmann P, Utzinger J, Wu Z. 2007. Molecular 
epidemiology of human Blastocystis in a village in Yunnan province, China. Parasitology International, 56, 281-286.

23. Li WC, Wang K, Gu Y. 2018. Occurrence of Blastocystis sp. and Pentatrichomonas hominis in sheep and goats in China. Parasites \& Vectors, 11, 93.

24. Li XM, Zhou H, Zhong DM, He JG. 1990. Diagnosis and treatment of two cases of Blastocystis hominis. Chinese Journal of Pediatrics, 28, 8.

25. Li XX, Chen JX, Wang LX, Tian LG, Zhang YP, Dong SP, Hu XG, Liu J, Wang FF, Wang Y. 2015. Prevalence and risk factors of intestinal protozoan and helminth infections among pulmonary tuberculosis patients without HIV infection in a rural county in P. R. China. Acta Tropica, 149, 19-26.

26. Lim YAL, Ngui R, Shukri J, Rohela M, Naim HRM. 2008. Intestinal parasites in various animals at a zoo in Malaysia. Veterinary Parasitology, 157, 154-159.

27. Mónica S, María Teresa GMO, Gloria SA, Ronald F. 2011. Development of a new PCR protocol to detect and subtype Blastocystis spp. from humans and animals. Parasitology Research, 109, 205-212.

28. Matsumoto Y, Yamada M, Yoshida Y. 1987. Lightmicroscopical appearance and ultrastructure of Blastocystis hominis, an intestinal parasite of man. Zentralblatt für Bakteriologie Mikrobiologie und Hygiene, 264, 379-385.

29. Mattiucci S, Crisafi B, Gabrielli S, Paoletti M, Cancrini G. 2016. Molecular epidemiology and genetic diversity of Blastocystis infection in humans in Italy. Epidemiology and Infection, 144, 635-646.

30. Mehlhorn H, Tan KSW, Yoshikawa H. 2012. Blastocystis: pathogen or Passenger? Springer Berlin Heidelberg. 225 p.

31. Moe KT, Singh M, Howe J, Ho LC, Tan SW, Ng GC, Chen XQ, Yap EH. 1996. Observations on the ultrastructure and viability of the cystic stage of Blastocystis hominis from human feces. Parasitology Research, 82, 439-444.

32. Moosavi A, Haghighi A, Mojarad EN, Zayeri F, Alebouyeh M, Khazan H, Kazemi B, Zali MR. 2012. Genetic variability of Blastocystis sp. isolated from symptomatic and asymptomatic individuals in Iran. Parasitology Research, 111, 2311-2315.

33. Nagel R, Cuttell L, Stensvold CR, Mills PC, Bielefeldt-Ohmann H, Traub RJ. 2012. Blastocystis subtypes in symptomatic and asymptomatic family members and pets and response to therapy. Internal Medicine Journal, 42, 1187-1195.

34. Navarro C, Domínguez-Márquez MV, Garijo-Toledo MM, Vega-García S, Fernández-Barredo S, Pérez-Gracia MT, García A, Borrás R, Gómez-Muñoz MT. 2008. High prevalence of Blastocystis sp. in pigs reared under intensive growing systems: frequency of ribotypes and associated risk factors. Veterinary Parasitology, 153, 347-358.

35. Parkar U, Traub RJ, Vitali S, Elliot A, Levecke B, Robertson I, Geurden T, Steele J, Drake B, Thompson RCA. 2010. Molecular characterization of Blastocystis isolates from zoo animals and their animal-keepers. Veterinary Parasitology, 169, 8-17.

36. Poirier P, Wawrzyniak I, Albert A, El Alaoui H, Delbac F, Livrelli V. 2011. Development and evaluation of a real-time PCR assay for detection and quantification of Blastocystis parasites in human stool samples: prospective study of patients with hematological malignancies. Journal of Clinical Microbiology, 49, 975-983.

37. Quílez J, Sánchez-Acedo C, Clavel A, Causapé AC. 1995. Occurrence of Blastocystis sp. in cattle in Aragón, northeastern Spain. Parasitology Research, 81, 703-705.

38. Riisberg I, Orr RJS, Kluge R, Shalchian-Tabrizi K, Bowers HA, Patil V, Edvardsen B, Jakobsen KS. 2009. Seven gene phylogeny of Heterokonts. Protist, 160, 191-204.
39. Roberts T, Barratt J, Harkness J, Ellis J, Stark D, Roberts T, Barratt J, Harkness J, Ellis J, Stark D. 2011. Comparison of microscopy, culture, and conventional polymerase chain reaction for detection of Blastocystis sp. in clinical stool samples. American Journal of Tropical Medicine \& Hygiene, 84, 308.

40. Roberts T, Stark D, Harkness J, Ellis J. 2013. Subtype distribution of Blastocystis isolates from a variety of animals from New South Wales, Australia. Veterinary Parasitology, 196, 85-89.

41. Ronald F, Monica S, Dumitru M. 2012. Detection of concurrent infection of dairy cattle with Blastocystis, Cryptosporidium, Giardia, and Enterocytozoon by molecular and microscopic methods. Parasitology Research, 111, 1349-1355.

42. Sarinee J, Porntip P, Kookwan S, Somchai P, Arunnee S, Chotechana W, Wachanan W, Hisao Y. 2013. Subtype identification of Blastocystis spp. isolated from patients in a major hospital in northeastern Thailand. Parasitology Research, 112, 1781-1786.

43. Silberman JD, Sogin ML, Leipe DD, Clark CG. 1996. Human parasite finds taxonomic home. Nature, 380, 398-398.

44. Song JK, Hu RS, Fan XC, Wang SS, Zhang HJ, Zhao GH. 2017. Molecular characterization of Blastocystis from pigs in Shaanxi province of China. Acta Tropica, 173, 130-135.

45. Song JK, Yin YL, Yuan YJ, Tang H, Ren GJ, Zhang HJ, Li ZX, Zhang YM, Zhao GH. 2017. First genotyping of Blastocystis sp. in dairy, meat, and cashmere goats in northwestern China. Acta Tropica, 176, 277-282.

46. Souppart L, Moussa H, Cian A, Sanciu G, Poirier P, Alaoui HE, Delbac F, Boorom K, Delhaes L, Dei-Cas E. 2010. Subtype analysis of Blastocystis isolates from symptomatic patients in Egypt. Parasitology Research, 106, 505-511.

47. Steinmann P, Du ZW, Wang LB, Wang XZ, Jiang JY, Li LH, Marti H, Zhou XN, Utzinger J. 2008. Extensive multiparasitism in a village of Yunnan province, People's Republic of China, revealed by a suite of diagnostic methods. American Journal of Tropical Medicine \& Hygiene, 78, 760-769.

48. Stensvold CR, Alfellani MA, Nørskov-Lauritsen S, Prip K, Victory EL, Maddox C, Nielsen HV, Clark CG. 2009. Subtype distribution of Blastocystis isolates from synanthropic and zoo animals and identification of a new subtype. International Journal for Parasitology, 39, 473-479.

49. Taamasri P, Mungthin M, Rangsin R, Tongupprakarn B, Areekul W, Leelayoova S. 2000. Transmission of intestinal blastocystosis related to the quality of drinking water. Southeast Asian Journal of Tropical Medicine and Public Health, 31, 112-117.

50. Tai WP, Hu PJ, Wu J, Lin XC. 2011. Six ulcerative colitis patients with refractory symptoms co-infective with Blastocystis hominis in China. Parasitology Research, 108, 1207-1210.

51. Tan KS. 2004. Blastocystis in humans and animals: new insights using modern methodologies. Veterinary Parasitology, 126, 121-144.

52. Tan KS. 2008. New insights on classification, identification, and clinical relevance of Blastocystis spp. Clinical Microbiology Reviews, 21, 639.

53. Tan TC, Tan PC, Sharma R, Sugnaseelan S, Suresh KG. 2013. Genetic diversity of caprine Blastocystis from Peninsular Malaysia. Parasitology Research, 112, 85-89.

54. Tang N, Luo NJ. 2016. A cross-sectional study of intestinal parasitic infections in a rural district of west China. Canadian Journal of Infectious Diseases, 14, 159-162.

55. Wang J, Gong B, Yang F, Zhang W, Zheng Y, Liu A. 2018. Subtype distribution and genetic characterizations of Blastocystis in pigs, cattle, sheep and goats in northeastern China's 
Heilongjiang Province. Infection, Genetics and Evolution, 57, 171-176.

56. Wang J, Gong B, Liu X, Zhao W, Bu T, Zhang W, et al. 2018. Distribution and genetic diversity of Blastocystis subtypes in various mammal and bird species in northeastern China. Parasites and Vectors, 11, 522.

57. Wang KX, Li CP, Wang J, Cui YB. 2002. Epidemiological survey of Blastocystis hominis in Huainan City, Anhui Province, China. World Journal of Gastroenterology, 8, 928-932.

58. Gorchev HG, Ozolins G. 1984. WHO Guidelines for Drinkingwater Quality. WHO Chronicle, 38, 104-108.

59. Wu GH, Xiong YS, Cao GL, Li GM, Liu MZ, Zhu JL. 2000. Investigation of an epidemic outbreak of Blastocystis. Chinese Journal of Parasitic Diseases Control, 13, 25-27.

60. Yamada $M$, Yoshikawa $H$, Tegoshi $T$, Matsumoto $Y$, Yoshikawa T, Shiota T, Yoshida Y. 1987. Light microscopical study of Blastocystis spp. in monkeys and fowls. Parasitology Research, 73, 527.

61. Yan Y, Su S, Ye J, Lai X, Lai R, Liao H, Chen G, Zhang R, Hou Z, Luo X. 2007. Blastocystis sp. subtype 5: a possibly zoonotic genotype. Parasitology Research, 101, 1527-1532.
62. Yoshikawa H, Yoshida K, Nakajima A, Yamanari K, Iwatani S, Kimata I. 2004. Fecal-oral transmission of the cyst form of Blastocystis hominis in rats. Parasitology Research, 94, 391-396.

63. Yoshikawa H, Wu Z, Pandey K, Pandey BD, Sherchand JB, Yanagi T, Kanbara H. 2009. Molecular characterization of Blastocystis isolates from children and rhesus monkeys in Kathmandu, Nepal. Veterinary Parasitology, 160, 295-300.

64. Zanzani SA, Gazzonis AL, Epis S, Manfredi MT. 2016. Study of the gastrointestinal parasitic fauna of captive non-human primates (Macaca fascicularis). Parasitology Research, 115, 307-312.

65. Zhang SX, Zhou YM, Xu W, Tian LG, Chen JX, Chen SH, Dang ZS, Gu WP, Yin JW, Serrano E. 2016. Impact of co-infections with enteric pathogens on children suffering from acute diarrhea in southwest China. Infectious Diseases of Poverty, 5, 64.

66. Zhang W, Ren G, Zhao W, Yang Z, Shen Y, Sun Y, Liu A, Cao J. 2017. Genotyping of Enterocytozoon bieneusi and subtyping of Blastocystis in cancer patients: Relationship to diarrhea and assessment of zoonotic transmission. Frontiers in Microbiology, 8, 1835.

Cite this article as: Deng L, Chai Y, Zhou Z, Liu H, Zhong Z, Hu Y, Fu H, Yue C \& Peng G. 2019. Epidemiology of Blastocystis sp. infection in China: a systematic review. Parasite 26, 41.

Reviews, articles and short notes may be submitted. Fields include, but are not limited to: general, medical and veterinary parasitology; morphology, including ultrastructure; parasite systematics, including entomology, acarology, helminthology and protistology, and molecular analyses; molecular biology and biochemistry; immunology of parasitic diseases; host-parasite relationships; ecology and life history of parasites; epidemiology; therapeutics; new diagnostic tools.

All papers in Parasite are published in English. Manuscripts should have a broad interest and must not have been published or submitted elsewhere. No limit is imposed on the length of manuscripts.

Parasite (open-access) continues Parasite (print and online editions, 1994-2012) and Annales de Parasitologie Humaine et Comparée (1923-1993) and is the official journal of the Société Française de Parasitologie. 